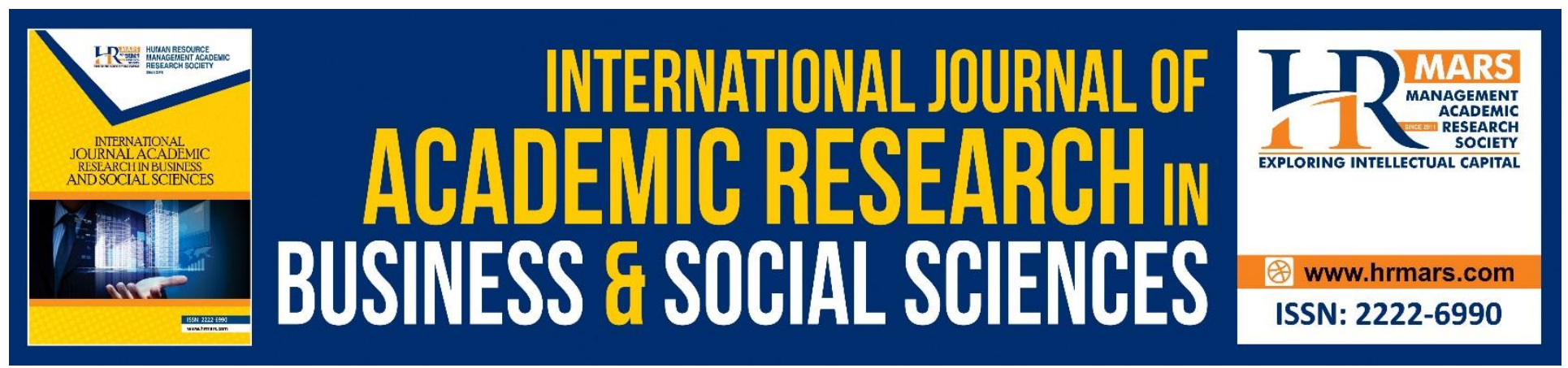

\title{
The Approaches that Influence Call Centre Employees' Motivation in Malaysian Outsourcing Company
}

Muhammad Hafiz Abd Rashid, Muhammad Iskandar Hamzah, Abd Kadir Othman, Aida Azlina Mansor and Rahayu Hasanordin

To Link this Article: http://dx.doi.org/10.6007/IJARBSS/v8-i11/4922 DOI: $10.6007 /$ IJARBSS/v8-i11/4922

Received: 26 July 2018, Revised: 14 Aug 2018, Accepted: 26 Oct 2018

Published Online: 28 Nov 2018

In-Text Citation: (Rashid, Hamzah, Othman, Mansor, \& Hasanordin, 2018)

To Cite this Article: Rashid, M. H. A., Hamzah, M. I., Othman, A. K., Mansor, A. A., \& Hasanordin, R. (2018). The Approaches that Influence Call Centre Employees' Motivation in Malaysian Outsourcing Company. International Journal of Academic Research in Business and Social Sciences, 8(11), 475-483.

Copyright: (C) 2018 The Author(s)

Published by Human Resource Management Academic Research Society (www.hrmars.com)

This article is published under the Creative Commons Attribution (CC BY 4.0) license. Anyone may reproduce, distribute, translate and create derivative works of this article (for both commercial and non-commercial purposes), subject to full attribution to the original publication and authors. The full terms of this license may be seen

at: http://creativecommons.org/licences/by/4.0/legalcode

Vol. 8, No. 11, 2018, Pg. 475 - 483

http://hrmars.com/index.php/pages/detail/IJARBSS

JOURNAL HOMEPAGE

Full Terms \& Conditions of access and use can be found at http://hrmars.com/index.php/pages/detail/publication-ethics 


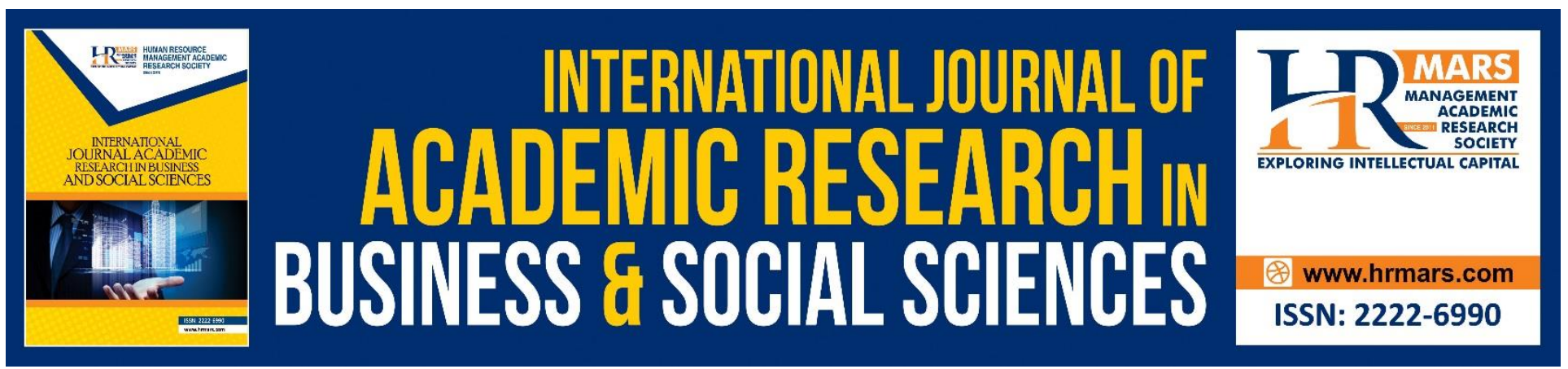

\title{
The Approaches that Influence Call Centre Employees' Motivation in Malaysian Outsourcing Company
}

\author{
Muhammad Hafiz Abd Rashid, Muhammad Iskandar Hamzah, Abd \\ Kadir Othman, Aida Azlina Mansor and Rahayu Hasanordin \\ Faculty of Business and Management, Universiti Teknologi MARA, 42300 Puncak Alam, Selangor \\ Email: hafiz.rashid@puncakalam.uitm.edu.my
}

\begin{abstract}
Effective approaches to motivate employees can be seen as the essential supplemental nutrition for enhancing employees' performance in any service business. Due to this notion, this study seeks to investigate the approaches that can influence the motivation level of call centre employees in outsourcing company in Malaysia. Malaysia has become as one of the popular destination for outsourcing besides India and Philippines. The availability of local graduates and their ability to converse in English were believed to be among the popular reasons. There are various approaches that could be employed to measure the level of employee's motivation. However, the researcher plans to employ the approaches consisting of employee ownership, teamwork/gain sharing, pay for knowledge, pay for performance and job enrichment for this study. By conducting this study, outsourcing companies will be able to gain insight that can help them to improve which indirectly will boost employee's motivation and satisfaction.
\end{abstract}

Keywords: Motivation, Employees, Call Centre, Outsourcing Company, Malaysia

\section{Introduction}

In today's competitive environment, service organizations have to realize the importance of retaining the best employees as an asset to succeed in their business. Employees who perform well in their task are always driven by a high level of motivation (Eke, 2018; Jensen, 2018). In recent years, Malaysia has become as one of the hubs for call centre outsourcing. Due to this notion, it is essential to study the approaches that motivate call centre employees to perform well in their job. The motivation level will impact the level of service quality rendered by the employees. According to Darrington and Howell (2011), motivation is the term used to describe the reason why an individual performs his / her task. Employees' motivation can be analysed from absence rate, leave rate, turnover rate, get-to-work speed and some other possible reasons (Hong, Yang, Wang, Chiou and Huang, 1995). In order to get the best out of the employees, managers need to understand what motivates employees within the scope of the tasks they perform (De Vito, Brown, Bannister, Cianci, 
\& Mujtaba, 2018; Schreiner, 2018). Motivating employees is undeniably the most complex of all the functions a manager performs. This is due to the fact that employee's motivation changes constantly from to time (Bowen and Radhakrishna, 1991). Past literature demonstrates that there are a number of approaches that have been used to measure employee's motivation level. However, the current study will only cover the approaches that were introduced by Daft (2008) which is teamwork (also known as gain sharing), employee ownership, pay for knowledge and pay for performance as well as job enrichment. This is due to the notion that the application of these approaches were still limited especially in Malaysian outsourcing companies.

\section{Literature Review \\ Employee's Motivation}

Employee's motivation is very critical to ensure daily business operations could be executed as planned. In fact, it is one of the most vital and essential components for the achievement of employees' and ultimately organizational targets and aims (Berman, Bowman, West and Wart, 2010). According to Armstrong (2006), motivation is a goal-directed behaviour which involves taking a course of action which leads to the attainment of a goal or a specific valued reward. Highly motivated employees are considered as an important asset to an organization because they tend to be more productive and higher productivity will usually results in higher outcomes (Eke, 2018; Jensen, 2018). The level of employee's motivation could be gauged by the volume of employees' turn over during a certain period of time. Well motivated employees are more focused towards their jobs and will likely to have less turnover intensions and are more motivated to be loyal with the organization (Bashaw and Grant, 1994). In addition, employee's motivation is in fact a vital component of business operations because high motivation coincides with job satisfaction, a sense of pride in one's work, a lifelong commitment to one's organization, and the desire to put the achievement of organizational goals ahead of personal goals which will lead to improvement in an organization's performance and productivity (Linz, Good and Huddleston, 2006).

\section{The Approaches that Influence Employee's Motivation}

There is no specific way in motivating employees as it may varies depending on the organization. The best employee's motivation efforts will focus on what the employees deem to be important (Schreiner, 2018). There are several approaches can that influence call centre employee's motivation in outsourcing company. The researcher plans to adopt the approaches introduced by Daft (2008) which is teamwork / gain sharing, employee ownership, pay for knowledge and pay for performance as well as job enrichment. The following section provides literature review pertaining to the approaches introduced by Daft (2008).

\section{Teamwork / Gain sharing}

Gain sharing focuses on individuals working together to achieve goals and rewards (Daft, 2008). On the other hand, Khalid Al-Rawi (2008) described that teamwork is related to a small number of individuals with complementary skills who are committed to a common objective, performance goals, and approach for which they hold themselves mutually accountable. However, effective teamwork is not easy to achieve and it does not just happen overnight; it takes a huge amount of hard work and 
INTERNATIONAL JOURNAL OF ACADEMIC RESEARCH IN BUSINESS AND SOCIAL SCIENCES Vol. 8, No. 11, Nov, 2018, E-ISSN: 2222-6990 @ 2018 HRMARS

compromise. Continuous training and education are crucial to boost team's confidence and capability as it can help to maintain the momentum in employee's motivation and eagerness for improvement (Koch, 1995). Therefore, based on the preceding discussion, the following proposition is formed:

P1: Teamwork significantly influences employee's motivation in outsourcing company.

\section{Employee Ownership}

Employee ownership is an opportunity (or a demand) to push (and perhaps pull) decision making downward. One of the ways to demonstrate employee ownership is by allowing the employees to participate in decision making process. Consistent with Bartkus (1997), participation in decision making requires that managers are willing to share decision making with lower level workers, and that lower level workers are actively willing to share responsibility for decisions. Employee participation within the organization is generally regarded as vital in generating and sustaining company loyalty and commitment to the organization (Michie and Oughton, 2001). However, employee ownership is not always viewed as a positive approach as some managers may be worried about losing their jobs and start to prevent sharing the decision making process with their subordinates. Consistent with Bartkus (1997), increasing autonomy and decision making at lower levels of an organization can possibly reduce the number of managers and supervisors. In the same study, Bartkus (1997) mentioned that management's reluctance to encourage lower level decision making is encouraged by two related factors. The first is the belief that decision making should be done at the level that has the most information and the second factor is management's propensity to withhold information which makes the belief that strategic decisions should be limited to the corporate level a necessity. Therefore, taken together the discussion, the following proposition is forwarded:

P2: Employee ownership significantly influences employee's motivation in outsourcing company.

\section{Pay for Knowledge}

There are various terms used to describe pay for knowledge. Pay-for-knowledge systems are sometimes called skill-based compensation, knowledge-based pay, multi-skill compensation, pay-forskill, job enrichment progressions, and so on. Regardless of the name, the concept of pay for knowledge is designed to offer higher base wages to employees who can perform a larger amount of task efficiently (Parent and Weber, 1994). Thus, it will influence employees to perform well and more than what they are expected to deliver. According to Celani and Weber (1997), there are at least three types of skills for which workers can be compensated which consist of depth skills, breadth skills, and vertical skills. The first skill is depth skills. Workers who acquire depth skills are being compensated for increasing their knowledge, skills, and abilities within a particular job category. Rewarding on the basis of depth skills can typically be found in blue-collar skilled trades. The compensation of depth skills is also found in white-collar occupations where a technical ladder is used to reward scientists and engineers for gaining greater knowledge and expertise in their particular field of research and study. Another skill in which the workers can be compensated is breadth skills. Workers are rewarded for learning skills to perform other jobs within their production line or work 
INTERNATIONAL JOURNAL OF ACADEMIC RESEARCH IN BUSINESS AND SOCIAL SCIENCES Vol. 8, No. 11, Nov, 2018, E-ISSN: 2222-6990 @ 2018 HRMARS

group. Other than that, vertical skill is also one of the important skills that the workers need to possess in order to get rewarded. Vertical skills are self-management skills that are expected of supervisory and managerial employees. Such vertical skills involve scheduling, training, communication, and problem solving. Therefore, in relation to the above discussion, the following proposition is formed:

P3: Pay for knowledge significantly influences employee's motivation in outsourcing company.

\section{Pay for Performance}

The mechanism behind pay-for-performance approach suggests that pay is linked to performance by setting specific targets and then rewarding employees for attaining these targets (Stringer, Didham and Theivanathampillai, 2011). The application of pay-for-performance may increase employees' job quality and become more productive. Thus, the employees will become more motivated to compete with their colleagues in completing the task given. Smith and Rupp (2003) wrote the literature over the past 15 years has looked at the effectiveness of pay for performance systems, employee reactions and acceptance towards the implementation of these systems, and specific relationships between performance and pay in relation to turnover, social recognition, and feedback. In a different view, Luthans and Stajkovic (1999) proposed that pay for performance systems are ineffective because the "rewards" or pay need to be replaced by reinforces. They imply that you do not necessarily get what you pay for, but you do get what you reinforce. As a result, they feel that rewards may do more harm than good. On the contrary, Landry et al. (2017) found that pay for performance was positively related to satisfaction and employee's motivation. Therefore, based on the above discussion, the following proposition is developed:

P4: Pay for performance significantly influences employee's motivation in outsourcing company.

\section{Job Enrichment}

Job enrichment incorporates high level motivators into the work, including job responsibility, recognition, and opportunities for growth and learning, and achievement. In an enriched job, the employee controls resources needed to perform well and makes decisions on how to do the work. One way to enrich an oversimplified job is to enlarge it, that is, to extend the responsibility to cover several tasks instead of only one (Daft, 2008). Companies that provide job enrichment opportunity will encourage employees to learn new skills, reduce boredom and receive recognition (Brookins, 2006). Job enrichment can motivate employees to come to work and this is supported by Walsh (1993) who stated that job enrichment is one of the methods to persuade people to come to work for us in the first place; to stick to us when they have come; and to put their best feet forward in getting the job done. Based on the aforementioned discussion, the following proposition is forwarded:

P5: Job enrichment significantly influences employee's motivation in outsourcing company. 
INTERNATIONAL JOURNAL OF ACADEMIC RESEARCH IN BUSINESS AND SOCIAL SCIENCES

Vol. 8, No. 11, Nov, 2018, E-ISSN: 2222-6990 (C) 2018 HRMARS

\section{Conceptual Framework}

The relationship between the approaches that influence motivation of call centre employees is summarized in the following framework:

Figure 1:

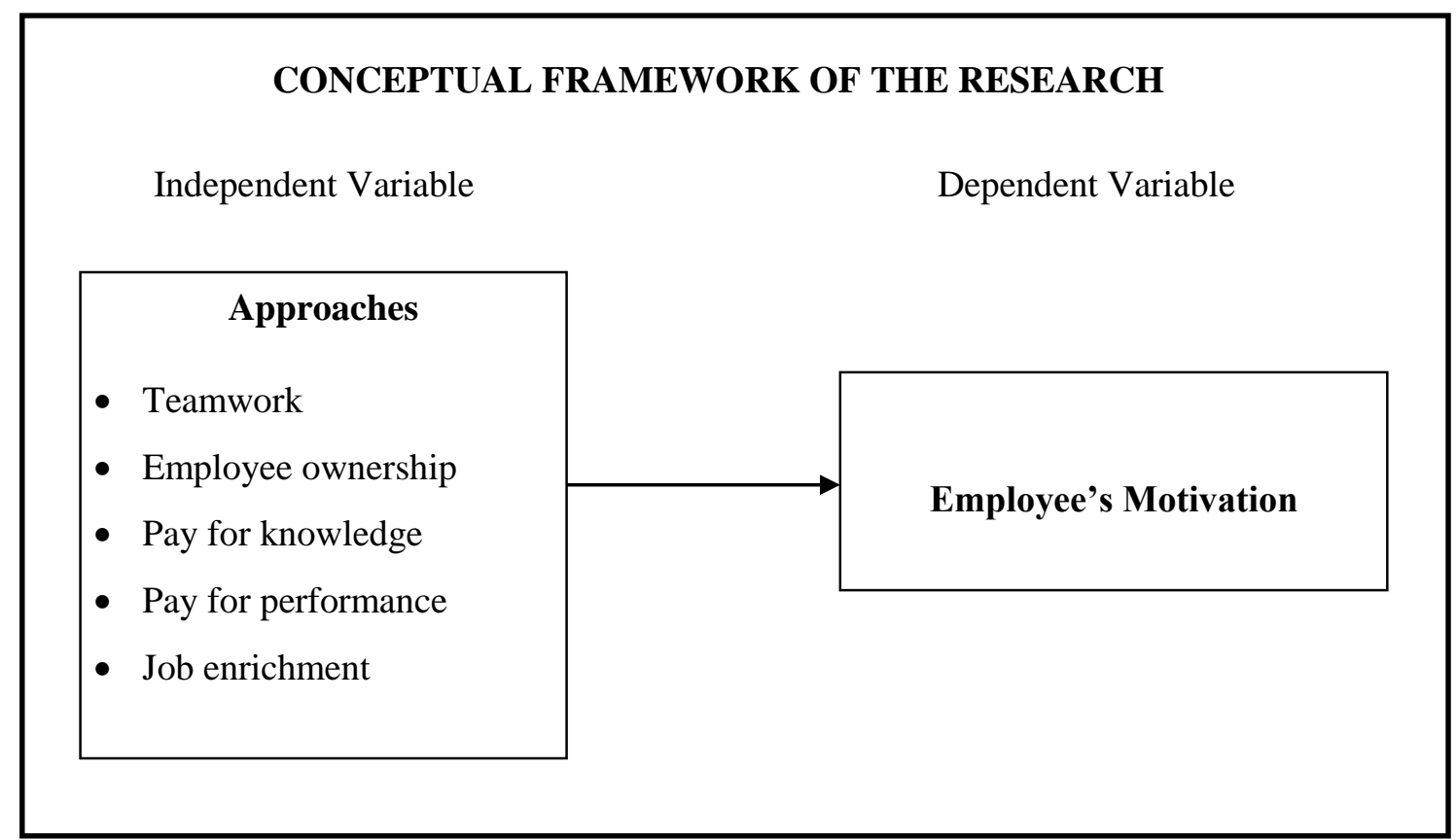

Conceptual Framework on the Approaches that Influence Motivation of Call Centre Employees in Malaysian Outsourcing Company.

\section{Conclusion}

Malaysia has been the outsourcing hub for local and multinational companies across the globe. This is due to the availability of local manpower and their ability to converse in various languages especially English. There are a number of studies that have been researching on the approaches that may influence employee's motivation. However, only limited number of research focuses on outsourcing companies, particularly in Malaysian context. The dearth of studies in this setting indicates a gap that needs to be filled. Since it is expected that the proposed approaches might have significant relationship on employee's motivation, it is worthwhile to explore the influence of this approaches.

\section{Implication for Managers}

In today's business environment, most organizations choose to outsource their call centre operation. Therefore, this area is worth researching since it can help outsourcing company to understand the approaches that can possibly influence the level of motivation among their call centre employees. It is also expected that the outsourcing companies could be more concern towards the individual needs 
INTERNATIONAL JOURNAL OF ACADEMIC RESEARCH IN BUSINESS AND SOCIAL SCIENCES

Vol. 8, No. 11, Nov, 2018, E-ISSN: 2222-6990 @ 2018 HRMARS

of their employees. This would enable the outsourcing company to retain their employees for long term and it can strengthen their reputation to compete with other companies.

\section{Recommendations for Future Research}

This study focuses on one particular setting (outsourcing industry) only and in a specific country (Malaysia); the findings that will be produced cannot be generalized to other settings and different geographical areas. Therefore, it is recommended that future research can replicate this study in other settings and different countries. Future research may be performed by taking a larger sample which may provide a more comprehensive result. On the other hand, future research may include some other moderating or mediating variables in investigating the approaches that influence employee's motivation.

\section{References}

Armstrong, M. (2006). Motivation: A Handbook of Human Resource Management Practice. London: Kogan Page Limited.

Bartkus, B. R. (1997). "Employee ownership as catalyst of organizational change", Journal of Organizational Change Management, Vol. 10 Iss: 4 pp. 331 - 344.

Bashaw, R.E. and Grant, E.S. (1994). "Exploring the distinctive nature of work commitments: Their relationships with personal characteristics, job performance, and propensity to leave", Journal of Personal Selling \& Sales Management, Vol. 14, pp. 1-16.

Berman, E.M., Bowman, J.S., West, J.P. and Wart, M.R.V. (2010). "Motivation: Possible, Probable or Impossible?", Human Resource Management in Public Service: Paradoxes, Processes and Problems, pp. 180.

Bowen, B.E and Radhakrishna R.B (1991). Job Satisfaction of Agricultural Education Faculty: A Constant Phenomena, Journal of Agricultural Education, Vol. 32, No.2, 16-22.

Brookins, M. (2006). The Advantages and Disadvantages of Job Enrichment. Human Resource Management. New Jersey: Pearson Education.

Celani, A. and Weber, C.L. (1997). Definition of a PFK Compensation System. Pay-for-Knowledge Systems: Guidelines for Practice, pp.1-2.

Daft, R. L. (2008). The leadership experience (5th ed.). Mason, OH: South-Western Cengage Learning.

Darrington, J.W. and Howell, G.A. (2011), "Motivation and incentives in relational contracts", Journal of Financial Management of Property and Construction, Vol. 16, pp. 42-51. 
INTERNATIONAL JOURNAL OF ACADEMIC RESEARCH IN BUSINESS AND SOCIAL SCIENCES

Vol. 8, No. 11, Nov, 2018, E-ISSN: 2222-6990 (C) 2018 HRMARS

De Vito, L., Brown, A., Bannister, B., Cianci, M., \& Mujtaba, B. G. (2018). Employee motivation based on the hierarchy of needs, expectancy and the two-factor theories applied with higher education employees. IJAMEE.

Eke, G. J. (2018). Contemporary Issues in Employee Motivation and Performance in Organizations. Social Sciences, 5(1).

Hong, J.C., Yang, S.D., Wang, L.J., Chiou, E.F., Su, F.Y., Huang, S.L. (1995), “Impact of employee benefits on work motivation and productivity", International Journal of Career Management, Vol. 7, pp. 10-14.

Jensen, J. D. (2018). Employee Motivation: A Leadership Imperative. International Journal of Business Administration, 9(2), 93.

Khalid Al-Rawi, (2008),"Cohesiveness within teamwork: the relationship to performance effectiveness - case study", Education, Business and Society: Contemporary Middle Eastern Issues, Vol. 1 Iss: 2 pp. $92-106$.

Koch, H. C. H.(1995),"Motivating staff through teamwork: process review and data display", Health Manpower Management, Vol. 21 Iss: 4 pp. $32-36$.

Landry, A. T., Gagné, M., Forest, J., Guerrero, S., Séguin, M., \& Papachristopoulos, K. (2017). The Relation Between Financial Incentives, Motivation, and Performance. Journal of Personnel Psychology.

Linz, S.J., Good, L.K. and Huddleston, P. (2006). "Worker morale in Russia: an exploratory study", Journal of Managerial Psychology, Vol. 21, pp. 415-437.

Luthans, F. and Stajkovic, A.D. (1999). "Reinforce for Performance: The need to go Beyond Pay and Even Rewards", The Academy of Management Executive, Vol. 13, No. 2. Pp. 49-57.

Michie, J. and Oughton, C. (2001). "Employee share-ownership trusts and corporate governance", Corporate Governance, Vol. 1 Iss: 3 pp. $4-8$.

Parent, K. J. and Weber, C.L. (September, 1994). Does Paying for Knowledge Pay Off? Compensation \& Benefits Review, pp. 1-2.

Schreiner, L. (2018). The effects of remuneration and reward systems on employee motivation in Luxembourg: EIKV-Schriftenreihe zum Wissens-und Wertemanagement. 
INTERNATIONAL JOURNAL OF ACADEMIC RESEARCH IN BUSINESS AND SOCIAL SCIENCES

Vol. 8, No. 11, Nov, 2018, E-ISSN: 2222-6990 @ 2018 HRMARS

Smith, A.D. and Rupp, W.T. (2003),"Knowledge workers: exploring the link among performance rating, pay and motivational aspects", Journal of Knowledge Management, Vol. 7, pp. 107124.

Stringer, C., Didham, J. and Theivanathampillai, P., (2008). "Motivation, Pay Satisfaction, and Job Satisfaction of Front-line Employees", Qualitative Research in Accounting and Management, Vol. 8, No.2.

Walsh, B., (1993), "A practical Approach to Job Enrichment", Industrial and Commercial Training, Vol. 6, Iss: 4, pp. 185-187. 